\title{
Visual signalling and sexual selection in male fiddler crabs Uca tangeri
}

\author{
Claire Latruffe ${ }^{1, * * *}$, Peter K. McGregor ${ }^{1, * *}$, Rui F. Oliveira ${ }^{2}$ \\ ${ }^{1}$ Behaviour and Ecology Research Group, School of Biology, University of Nottingham, University Park, Nottingham NG7 2R0, \\ United Kingdom \\ ${ }^{2}$ Unidade de Investigaçāo em Eco-Etologia, Instituto Superior de Psicologia Aplicada, Lisboa, Portugal
}

\begin{abstract}
Similar to many other species of fiddler crabs, the interactions of Uca tangeri are influenced by 2 characteristic visual signals: the waving display performed by males with their enlarged claw, and the building of structures (mudballs) around the burrow entrance. This study focused on male signalling, male-male competition and female mate choice. Female choice and male mating success were investigated by looking at male quality, male visual signals (waving activity and mudballs) and male interactions and their outcome. Fieldwork was carried out in June and July 1997 at the Ria Formosa Natural Park. Algarve, Portugal, on a sandy beach with an average population density of 2.06 burrows $\mathrm{m}^{-2}$. Behavioural observations of focal males were made at low tide, $1 \mathrm{~h}$ before and after the peak of low tide, that is during the mudballing phase or interaction phase. This was also when measurements of male characteristics, mudballs and burrow characteristics were taken. The results show that the quality of a male's burrow is related to its depth, and depth is correlated with 4 features: claw size, waving rate, mean distance to mudballs and number of mudballs. Therefore, females could use these features as indicators of gallery depth, eliminating the need to enter the burrow for sampling. Males compete for the possession of burrows that are more visited by females, thus taking over burrows is an alternative strategy to burrow digging. Male waving activity, mudball distance and claw size can be considered as multiple visual signals available to females for mate choice. Females' first choice criterion would seem to be burrow quality.
\end{abstract}

KEY WORDS: Fiddler crabs · Visual signals · Male competition - Mate choice · Burrows

\section{INTRODUCTION}

Fiddler crabs (genus Uca [Brachyura, Ocypodidae]) inhabit diverse environments in most tropical and subtropical regions of the world. Uca tangeri is the only European fiddler crab species, with a large population on the southeastern coast of Portugal in the Ria Formosa intertidal zone (Wolfrath 1993).

Similar to many other fiddler crab species, mating decisions by females are influenced by 2 features: the waving display performed by males, and constructions resulting from substratum digging and placement around burrow entrances (Oliveira \& Custódio 1998,

\footnotetext{
•E-mail: clatruffe@zi.ku.dk

- Present address: Department of Animal Behaviour, University of Copenhagen, Tagensvej 16, 2200 Copenhagen N, Denmark
}

Oliveira et al. 1998). One of the male fiddler crab's chelipeds (front claws) is hypertrophied (Christy 1988). In Uca tangeri the enlarged claw is white, thus standing out clearly from the darkly-coloured carapace and the dark substratum background. This claw, which has lost its role in feeding, is known to function as a weapon in aggressive interactions and as a visual signal in courtship, where males wave their enlarged claw to attract females to their burrows for mating (Crane 1975). In the case of our study population of $U$. tangeri, the crabs constructed small balls of substratum ('mudballs') that they placed in front of and around their burrows (Oliveira et al. 1998). Unlike other species, both males and females engage in mudball formation; however, closer investigation has shown that males produce more and bigger mudballs and that they place them further away from the burrow entrance than females (Oliveira et al. 1998). Experi- 
ments have suggested that male mudballs play a role in territory defence and mate attraction, whereas female mudballs seem to be a by-product of digging out the burrow (Oliveira et al. 1998).

At any one time male Uca tangeri can be classified as resident (defending a burrow) or wandering (not defending a burrow). Both resident and wandering males were present in our population throughout the season, and individual males changed from resident to wandering (and vice versa) during a season.

Two main mechanisms of sexual selection can account for the exaggerated size of the claw in male fiddler crabs: male-male competition and female mate choice. Several studies on Uca species have highlighted the potential advantages of a large claw in males, particularly in male-male physical confrontations (including threats and fights) (Von Hagen 1962 for U. tangeri, Crane 1967 for U. rapax, Hyatt \& Salmon 1978 for $U$. pugilator). Enlarged claws may also be advantageous in mate attraction in terms of detection and attraction of wandering females: Backwell \& Passmore (1996) found that in $U$. annulipes mated males have a larger carapace and a larger claw than the population average, and experiments by Oliveira \& Custódio (1998) with $U$. tangeri showed that females approached males with larger claws significantly more often.

Evidence of the influence of female mate choice on the evolution of male visual characteristics has been found, in many species, to be omaments as varied as long tails in widowbirds Euplectes sp. (Andersson 1982, 1989) and guppies Poecilia reticulata (Bischoff et al. 1985), train size and number of ocelli in the peacock Pavo cristatus (Ridley 1981), dewlap color and display in Anolis lizards (Greenberg \& Noble 1944, Crews 1975, Sigmund 1983) or sword lengths in swordtails Xiphophorus sp. (Basolo 1990a, b).

The aim of the present study was to investigate female choice and mating success in male resident fiddler crabs by examining the relationship between male quality and visual signals such as waving and mudballing activities, as well as looking in detail at male-male competition and the outcome of interactions.

\section{METHODS}

Study area. The field work was carried out at the Ria Formosa Natural Park (southeastern coast of Algarve, Portugal), during June and July 1997. The Ria Formosa is a large lagoon formed by a succession of sand barrier islands that run along the coast, and is in permanent connection with the open sea. During low tide it consists mainly of mudflats and salt marshes. The study site, Marim, is situated $12 \mathrm{~km}$ east of Faro $\left(36^{\circ} 59^{\prime} \mathrm{N}\right.$, $7^{\circ} 51^{\prime} \mathrm{W}$ ), and consists of a sandy beach with an average density of Uca tangeri burrows of $2.06 \mathrm{~m}^{-2}$.

Behavioural observations. In our study site the tide regime is 1 low tide every $12 \mathrm{~h}$. Behavioural observations of 2 focal resident males ( $1 \mathrm{~h}$ per male) were made every day at low tide. One focal crab was observed during the hour that preceded low tide and the second one during the next hour. We adopted this observational procedure since it is known that the activity of male Uca tangeri during low tide can be divided into 3 consecutive phases of approximately $2 \mathrm{~h}$ each: first feeding, then mudballing and finally waving (Machado \& Oliveira unpubl. data). Most social interactions (visits/intrusions) occur during the mudballing phase. One observer made all $1 \mathrm{~h}$ observations and measurements of 18 males $\left(2\right.$ focal males $\mathrm{d}^{-1}$ for 9 d). A few observations and measurements of males and mudballs made by 3 other observers were also added.

During each focal observation the following variables were recorded: (1) All the occurrences of waving by the focal male. We distinguished between high and low intensity waving since they might be used in different contexts. In high intensity waving the body is raised and lowered and the frequency of claw waving increases (von Hagen 1962). High intensity waving must be considered with caution since this type of waving could be an effect rather than a cause of female visits (Crane 1975). During low intensity waving, waving movements are performed at a low rate and low amplitude. (2) All approaches and visits by females within $1 \mathrm{~m}$ of the focal male's burrow. In order to do this, small marks were drawn in the sand at $1 \mathrm{~m}$ distance around the focal's burrow entrance before the start of each observation session. (3) All approaches within $1 \mathrm{~m}$ of the focal male's burrow (see [2] above) and agonistic interactions with male intruders (wandering males or neighbouring residents). Crab behaviour was recorded according to ethograms provided by von Hagen (1962) and Crane (1975). The claw size of the intruder relative to that of the focal male was estimated visually. Claw sizes were considered to be equal if the difference in size was less than $2 \mathrm{~mm}$.

Male and burrow characteristics. To study the relationship between a male's characteristics, mudballs, burrow and mating success we also measured the following variables after completing the behavioural observations: (1) Male characteristics: (a) Body sizemeasured as carapace width with a vernier caliper to the closest mm (see Fig. 1A). (b) Claw size-measured with a vernier caliper as the length of the propodus of the enlarged cheliped (see Fig. 1A). (c) Carapace colour-individuals were classified into 1 of 4 colour classes: green, brown, orange and purple. (d) Handed- 
A

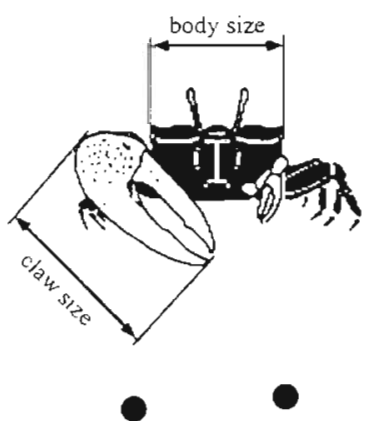

B

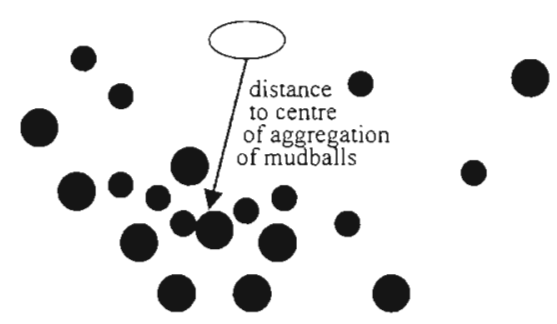

C

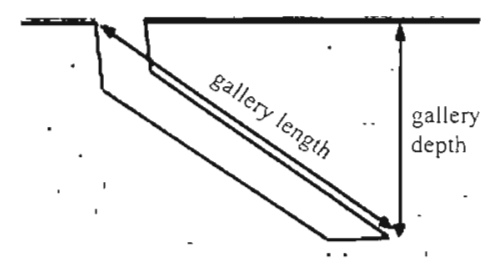

Fig. 1. Illustrations of measurements of aspects of males and burrows. (A) Frontal view of a male fiddler crab showing measurement of body size and claw size. (B) Burrow entrance (open ellipse) and mudball aggregation. (C) Section of an UCa tangeri gallery showing measurement of gallery length and gallery depth

ness - males were classified as either right-clawed or left-clawed according to which was the enlarged cheliped. (2) Mudballs: (a) Number of mudballs. (b) Distance to mudballs - measured as the distance between the burrow entrance and the centre of aggregation of the mudballs (see Fig. 1B \& Oliveira et al. 1998). (3) Burrow characteristics: (a) Gallery length - measured as the distance from burrow entrance to the bottom of the burrow (see Fig. 1C). (b) Gallery depthmeasured as the vertical distance between the surface and the end point of the gallery (see Fig. 1C).

Gallery length and gallery depth were measured at the end of each observation by carefully excavating the gallery. Males were then extracted from the bottom of the gallery, measured and identified with a piece of DYMO tape to ensure that each male only appeared once in the data set.

Female choice. We recorded the number of female visits (number of female approaches within $1 \mathrm{~m}$ of male burrows). In order to investigate the correlates of mat- ing success in male fiddler crabs we correlated the frequency of female visits (visits $\mathrm{min}^{-1}$ ) with potential visual signals (waving and mudballs) and burrow characteristics. The following variables were investigated: (1) Male characteristics: body size (i.e. carapace width), claw size, handedness (left/right clawed), colour, low and high intensity waving rates and mudballing rate (number of mudballs placed $\mathrm{min}^{-1}$ ). (2) Mudball characteristics: distance from the entrance of the burrow to the centre of aggregation of mudballs, and number of mudballs.

Statistical procedures. We used Pearson correlation coefficients (r), except when variables violated the assumptions of parametric statistics of normality (based on visual evaluation of normal probability plots) or homogeneity of variances (Levene test, Statsoft Inc. 1995), in which case we used the non-parametric Spearman correlation coefficient $\left(\mathrm{r}_{\mathrm{s}}\right)$.

We used a multiple regression to investigate the best predictors of male mating success (measured by the number of female visits received). The forward stepwise procedure was used with an $F=1.0$ criterion to insert a new variable into the model (Statsoft Inc.1995).

We used a program for the analysis of contingency tables using simulations (ACTUS) (Estabrook \& Estabrook 1989) which does not have the restrictions of conventional tests, such as low or null expected frequencies. This test has the additional advantage of allowing the determination of which cells differ significantly from chance levels, offering something similar to a post hoc test, in the case of non-independence between rows and columns.

\section{RESULTS}

\section{Visual signalling and mate quality}

In order to investigate whether male waving and mudballing signals could carry information, on male quality and/or on the quality of the male's burrow, which could be available to both females and other males, we correlated components of these signals (low intensity waving rate, claw size, distance to mudballs, and number of mudballs) and indicators of male quality (claw size and body size) and burrow characteristics (gallery depth). As gallery depth was significantly correlated to gallery length $\left(r_{\mathrm{s}}=0.65, \mathrm{n}=22, \mathrm{p}=0.001\right)$, we used only gallery depth as a burrow characteristic. We used claw size as both a component of the waving display and as an indicator of male quality since on the one hand it may increase the detectability of the waving male and on the other it may be a condition-dependent trait (Andersson 1994). Claw size, waving rate and mudballing were all significantly correlated with 
Table 1. Correlations between male characteristics and burrow characteristics. Values are Spearman correlation coefficients $(n)_{i} \cdot p<0.05, " p<0.01$

\begin{tabular}{|lccc|}
\hline Indicators & \multicolumn{2}{c}{ Male quality } & Burrow quality \\
& Claw size & Body size & Gallery depth \\
\hline Claw size & - & $0.37^{\circ}$ & $0.38^{\circ}$ \\
& & $(36)$ & $(35)$ \\
Low intensity & 0.27 & 0.10 & $0.50^{\circ}$ \\
waving rate & $(18)$ & $(18)$ & $(18)$ \\
Distance to & ${0.44^{\circ}}^{\circ}$ & 0.27 & $0.45^{\circ}$ \\
mudballs & $(29)$ & $(29)$ & $(28)$ \\
Number of & $0.34^{\circ}$ & 0.20 & $0.52^{*}$ \\
mudballs & $(32)$ & $(32)$ & $(31)$ \\
& & & \\
\hline
\end{tabular}

gallery depth, while only claw size showed a significant correlation with body size. Claw size and the distance to the centre of mudball aggregation were significantly positively correlated (see Table 1).

\section{Male-male competition}

To investigate the relationship between relative claw size and the outcome of the interactions (intrusions and fights) between focal (resident) males and intruders, we calculated the proportion of interactions with clear outcomes for each of the following relative claw size classes: resident $=$ intruder $(n=33)$, resident $>$ intruder $(n=51)$, resident < intruder $(n=17)$. There were more interactions with clear outcomes when the resident had a larger claw (76.5\%) than the reverse (51\%) (comparison of 2 proportions [R $>$ I vs $R<I], z=2.19$, $\mathrm{p}=0.03$ ). Considering the outcomes with a clear winner and a clear loser, males with larger claws won a significantly greater number of interactions (28 vs 11 , $\chi^{2}=7.41, \mathrm{p}<0.01$ ). Residents also won a significantly greater number of interactions than intruders (54 vs 5 , $\left.\chi^{2}=40.69, p \ll 0.01\right)$. The interaction between the resident effect and the relative claw size shows a nonsignificant tendency (see Table 2; ACTUS $\chi^{2}=4.31$, $\mathrm{p}=0.10$ ); moreover, resident males with larger claws were never observed to lose an interaction

The behaviour of the resident male was not independent of the relative claw size between resident and

Table 2. Interactions between residents (R) and intruders (I): the effect of relative claw size on interaction out-come. Values are numbers of occurrences

\begin{tabular}{|lcc|}
\hline Relative claw size & Resident wins & Intruder wins \\
\hline $\mathrm{R}=\mathrm{I}$ & 17 & 3 \\
$\mathrm{R}>\mathrm{I}$ & 26 & 0 \\
$\mathrm{R}<\mathrm{I}$ & 11 & 2 \\
\hline
\end{tabular}

Table 3. Interactions between residents and intruders: the effect of relative claw size on resident behaviour. Values are number of occurrences of a behaviour; (") low values, $(+)$ high values

\begin{tabular}{lrrr|}
\hline Resident behaviour & $\mathrm{R}=\mathrm{I}$ & $\mathrm{R}>\mathrm{I}$ & $\mathrm{R}<\mathrm{I}$ \\
\hline Ignore & 11 & 20 & 4 \\
React & 3 & 6 & 3 \\
Threat & 4 & 9 & 0 \\
Fight & 9 & 9 & 3 \\
Enter burrow & 3 & 0 & 1 \\
Low intensity waving & 1 & $0 \cdot$ & $4+$ \\
High intensity waving & 2 & 7 & 2 \\
\hline
\end{tabular}

intruder males (see Table 3; ACTUS $\chi^{2}=25.8, p<$ 0.01 ). The ACTUS procedure identified the value of low intensity waving towards larger intruders as being significantly high $(\mathrm{p}<0.01)$, and 2 cells in the table have quasi-significant low values: threat towards larger intruders $(\mathrm{p}=0.07)$ and low intensity waving towards smaller intruders ( $\mathrm{p}=0.06$ ). These results suggest that residents tended to switch from threatening intruders with relatively smaller claws to waving towards intruders with relatively larger claws.

The intruder pressure (i.e. number of intrusions and number of fights) was not correlated with any of the variables describing male or burrow characteristics (i.e. claw size, waving, number of mudballs and their distance from burrow; see Table 4), but both the number of male intrusions and the number of male fights were correlated with the number of female visits to the focal's burrow (see Table 4). Fights were considered separately from intrusions, and the number of fights was not significantly correlated with the number of intrusions $\left(r_{\mathrm{s}}=0.27, \mathrm{n}=59, \mathrm{p}=0.335\right)$.

Female choice. The number of female visits was significantly correlated with claw size $(r=0.38, p=0.007$, $n=49)$, low intensity waving rate $(r=0.58, p=0.01$,

Table 4. Correlations between intruder behaviour and aspects of male characteristics and male and female behaviours. Values are Spearman correlation coefficients $(n) ;{ }^{\circ} p<0.05$

\begin{tabular}{|lcc|}
\hline & Intrusions & Fights \\
\hline Claw size & 0.14 & 0.07 \\
Waving & $(36)$ & $(36)$ \\
& -0.08 & 0.04 \\
Number of mudballs & $(18)$ & $(18)$ \\
& -0.11 & 0.05 \\
Distance of mudballs & $(32)$ & $(32)$ \\
& 0.09 & 0.17 \\
Female visits & $(29)$ & $(29)$ \\
& $0.33^{\circ}$ & 0.40 \\
& $(36)$ & $(36)$ \\
\hline
\end{tabular}


$\mathrm{n}=18)$ and high intensity waving rate $(\mathrm{r}=0.71, \mathrm{p}=$ $0.001, n=18$ ) (see Fig. 2). The large correlation coefficient between high intensity waving rate and the number of female visits should be interpreted with caution since this type of waving by males is induced by the approach of females, and thus could be an effect and not a cause of female visits. The number of mudballs was not significantly correlated with the number of female visits $\left(r_{s}=-0.06, n=18, p=0.85\right)$.
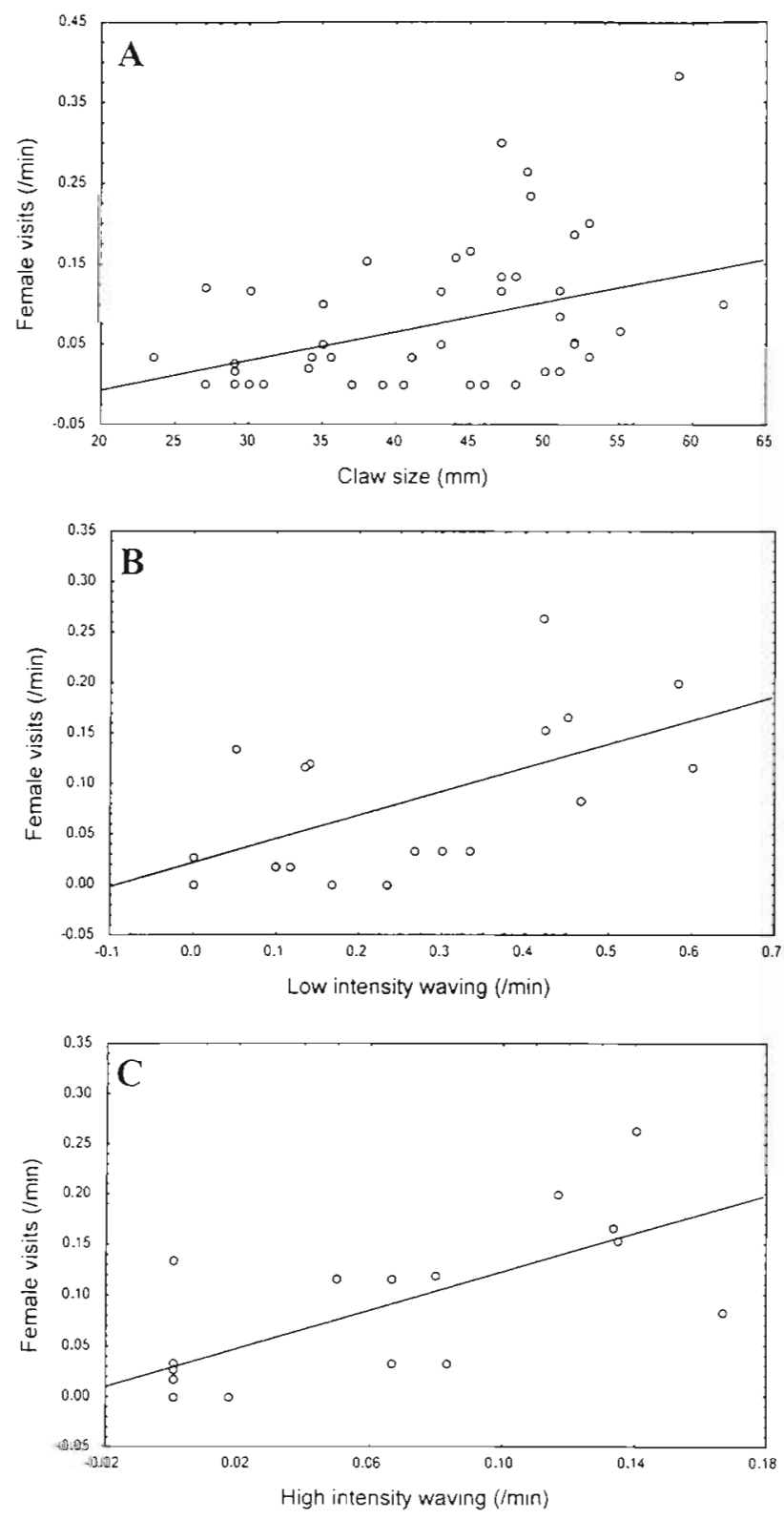

Fig. 2. Regression model. Relationship between female visits and 3 aspects of males. Female visits $\mathrm{min}^{-1}$ in relation to (A) male claw size $(n=43)$, (B) rate of low intensity waving by males ( $\mathrm{n}=18)$, and $(\mathrm{C})$ rate of high intensity waving by males $(\mathrm{n}=16)$
Neither the handedness of the males nor their colouration had a significant effect on the number of female visits received (Kruskal-Wallis test [n total $=31$ males] for brown [ $\mathrm{n}=8]$ vs green $[\mathrm{n}=6]$ vs orange [ $\mathrm{n}=$ 9] vs purple [n=8]: $H=2.41$, $\mathrm{df}=3, \mathrm{p}=0.49$; Mann Whitney $U$-test for left clawed vs right clawed: $\mathrm{n}_{\text {left }}=$ $\left.18, \mathrm{n}_{\text {right }}=18, \mathrm{z}=-0.4, \mathrm{p}=0.70\right)$.

To assess the relative importance of low intensity waving, mudball distance and claw size when taken together, a forward stepwise regression model was developed:

Female visits $=-0.06+0.71$ Low intensity waving rate -0.49 Mudball distance +0.38 Claw size + Error (E)

This model with 3 variables explained approximately $60 \%$ of the variance in female visits received by males. The intercept is not significantly different from zero and the regression coefficients for waving rate and distance to mudballs are both statistically significant ( $p<0.01$ and $p<0.05$ respectively).

\section{DISCUSSION}

\section{Visual signalling and mate quality}

The main information that could be derived from a male's waving and mudballing activities concerned his burrow: gallery depth was significantly positively correlated with the components of both signals: claw size, waving rate, distance to mudballs and number of mudballs. As male burrows are used as brood chambers, deeper galleries could be more advantageous than shallower galleries because they would be closer to the underlying ocean water layer and possess a microclimate with favourable humidity or oxygen conditions (Wolfrath 1992). Deeper galleries could also be less likely to collapse than long shallow galleries (Christy 1982). In Uca pugilator (Christy 1983) and $U$. beebei (Christy 1987), females also prefer deep, stable galleries, as these are least likely to flood or collapse causing females to lose eggs during incubation, and they may also provide a good thermal environment for incubation.

Taken together the results on visual signals and mate quality suggest that mudballing and low intensity waving can act as multiple visual signals allowing females to choose males with deeper galleries without having to enter the burrows for assessment. Gallery depth can be assessed by females through 4 indicators (claw size, waving rate, distance to mudballs, number of mudballs) without actually entering the burrow for sampling. Females could therefore avoid the risk of 
being trapped inside the burrow and forced to copulate. Males coerce females to mate with them in a wide range of species, one of the main forms of sexual coercion being forced copulation (Clutton-Brock \& Parker 1985). Sexual coercion can be so widespread in animal societies and have such important consequences in terms of evolution that Smuts \& Smuts (1993) consider that it should be regarded as a third form of sexual selection, along with intra-sexual competition and inter-sexual mate choice. Thus the risk of sexual coercion, and more specifically forced copulation, may act as a selection pressure for females to assess burrow quality through various visual signals from the males without actually entering the burrow.

\section{Male-male competition}

Males with larger claws won a significantly greater number of interactions, which confirms the advantages of a large claw in male-male physical confrontations. Residents won significantly more interactions than intruders. Furthermore resident males with larger claws were never observed to lose an interaction, whether the intruder was smaller, equal-sized or larger. These results suggest that resident crabs capitalize on 2 advantages: claw size and a resident effect. The same pattern was shown by Jennions \& Backwell (1996) in an investigation of the effect of residency and size on the fighting success of male Uca annulipes. In a series of field experiments where males were released in the colony after being removed from their burrows, the authors found that when controlling for body size, intruders with larger claws were more likely to win encounters than intruders with smaller claws, suggesting that, when body size is not a factor, claw size determines the outcome of the interaction. Jennions \& Backwell (1996) also found that residents won significantly more fights (a result also found by Hyatt \& Salmon [1978] with Uca pugilator and U. pugnax) the most likely explanation being that residents have a positional advantage (Christy 1982), in the form of an anchor to the burrow entrance or a refuge allowing partial retreat.

The number of intrusions and number of fights showed no significant correlation with any of the variables that could contain information on male or burrow quality (i.e. claw size, waving rate, number of mudballs and mudball distance). However, both the number of intrusions and the number of fights were significantly correlated with the number of female visits to the focal's burrow. These results suggest that males compete for the possession of burrows that are more visited by females, in the sense that males may observe females to detect high quality burrows and subse- quently try to take them over from their owners. Thus, one indirect route for males in the context of competition for females could be through the competition for good quality burrows. Such behaviour would be an alternative strategy for wandering males, who instead of following the strategy of digging out a new burrow for themselves, could try to take over a good quality burrow from resident males. Alternative strategies, by which individuals of the same population have more than one means of achieving the same functional end, have been demonstrated in many species (e.g. digging and entering digger wasps [Brockmann \& Dawkins 1979, Brockmann et al. 1979, Brockmann 1980\}), including other Crustacea species like horseshoe crabs Limulus polyphemus, where males have 2 different mating tactics (attached/satellite males) according to their age (Brockmann 1990, Brockmann \& Penn 1992, Brockmann 1996). It is important to note that in the case of our study species wandering males and burrow owner males do not form 2 distinct categories of males; therefore, digging out a burrow and taking over a good quality burrow may represent 2 different tactics that the same individual can use at different times.

\section{Female choice}

Male waving activity plays an important role in female attraction since female visits were highly correlated with low intensity waving rate (as shown both by the univariate statistics and the regression model). This confirms the role of male waving behaviour in mate attraction (Backwell \& Passmore 1996, Oliveira \& Custódio 1998). According to von Hagen (1962), high intensity waving is only performed when a female approaches the burrow of the male at a short range (approximately $30 \mathrm{~cm}$ ), therefore high intensity waving can be seen as a response to the presence of a female and thus should not be used as an indicator of female choice

The number of mudballs was not significantly correlated with the number of female visits. Therefore, although the number of mudbails was shown to contain information on gallery depth (cf. results on male quality), females were not using this information. In a series of field experiments using dummy resin-coated males, Oliveira et al. (1998) found that equal numbers of females entered the burrows of 2 males with a different number of mudballs ( 20 vs 30 ). Thus, despite the fact that mudballs may be an indicator of the presence of a male in the area as well as an indicator of its gallery depth (burrow quality), our results suggest that females do not base their choice on the number of mudballs itself, but on other visual signals like male waving rate and mudball distance. 
Waving activity, mudballs and claw size form a set of multiple visual signals, and females may integrate or discriminate between the available cues for mate choice. For example, in our study a dynamic signal like male waving was shown to be of importance in female choice. Yet, in previous experiments with dummy resin-coated males, there was no waving activity and females based their tendency to approach and speed of approach on the only indicator available, which was the presence/number of mudballs (Oliveira et al. 1998). Ostlund-Nilsson (1998) showed that female choice in three-spined sticklebacks Gasterosteus aculeatus was also based on several cues, more specifically that dominance was not the single most important character for females in mate choice in the absence of male-male interactions.

There was no significant difference in the number of female visits according to male handedness (left- or right-clawed males), which is consistent with the results of the experimental study by Oliveira \& Custódio (1998) and supported by the existence of an equal proportion of left- and right-clawed males in this population (Faria 1994). This suggests that there is no selection pressure favouring one side for the enlarged claw. Comparable results have been found for other species of fiddler crabs (Yamaguchi 1977. Ahmed 1978). Similarly, there was no significant difference in the number of female visits according to any of the 4 colour classes, these classes also being represented approximately equally in the population (von Hagen 1962, Wolfrath 1993).

The results on female choice, along with those on male quality, suggest that burrow quality is the most important feature in female choice, as measured by gallery depth, i.e. a good quality brood chamber will give direct benefits to females incubating eggs. In the study of mate choice in female Uca annulipes by Backwell \& Passmore (1996), burrow quality also emerged as an important and constant criterion in final mate choice, as it did in U. pugilator (Christy 1983). Burrow quality may indeed have a large influence on female reproductive success, in the sense that in the absence of paternal care direct benefits of female choice for defended resources (burrows) are likely to outweigh any indirect genetic benefits of choice based on male phenotype (Halliday 1983).

In their search for deep galleries, females may assess this quality of the gallery indirectly through multiple visual traits, among them the male's low intensity waving rate and claw size, rather than directly through the quality (composition) of the mudballs. The fact that waving activity was not significantly correlated with any of the male's characteristics (claw size or body size), but that it was strongly correlated with gallery depth, suggests it is a better indicator of burrow quality than of male quality.

Acknowledgements. This research was funded through an ASAB Vacation Scholarship to C.L. We thank Ria Formosa Natural Park, Portugal, for permission to work in the Park and logistic support. Colleagues in ISPA, Lisbon, and BERG, Nottingham, provided great support at diverse stages of the study.

\section{LITERATURE CITED}

A.hmed M (1978) Development of asymmetry in the fiddler crab Uca cumulanta, Crane 1943 (Decapoda: Brachyura). Crustaceana 34:294-300

Andersson M (1982) Female choice selects for extreme tail length in a widowbird. Nature 299:818-820

Andersson M (1994) Sexual selection. Princeton University Press, Princeton

Andersson S (1989) Sexual selection and cues for female choice in leks of Jackson's widowbird Euplectes jacksoni. Behav Ecol Sociobiol 25:403-410

Backwell PRY, Passmore NI (1996) Time constraints and multiple choice criteria in the sampling behaviour and mate choice of the fiddler crab Uca annulipes. Behav Ecol Sociobiol 38:407-416

Basolo A (1990a) Female preference for male sword length in the green swordtail Xiphophorus helleri (Pisces: Poeciliidae). Anim Behav 40:332-338

Basolo A (1990b) Female preference predates the evolution of the sword in swordtail fish. Science 250:808-810

Bischoff RJ, Gould JL, Rubinstein DI (1985) Tail size and female choice in the guppy. Behav Ecol Sociobiol 17 $253-255$

Brockmann HJ (1980) The control of nest depth in a digger wasp (Sphex ichneumoneus). Anim Behav 28:426-445

Brockmann HJ (1990) Mating behavior of horseshoe crabs Limulus polyphemus. Behaviour 114:206-220

Brockmann HJ (1996) Satellite male groups in horseshoe crabs Limulus polyphemus. Ethology 102:1-21

Brockmann HJ, Dawkins R (1979) Joint nesting in a digger wasp as an evolutionarily stable preadaptation to social life. Behaviour 71:203-245

Brockmann HJ, Penn D (1992) Male mating tactics in the horseshoe crab Limulus polyphemus. Anim Behav 44: 653-665

Brockmann HJ, Grafen A, Dawkins R (1979) Evolutionarily stable nesting strategy in a digger wasp. J Theor Biol 77 : $473-496$

Christy JH (1982) Burrow structure and use in the sand fiddler crab Uca pugilator (Bosc). Anim Behav 30:687-694

Christy JH (1983) Female choice in the resource-defense mating system of the sand fiddler crab Uca pugilator. Behav Ecol Sociobiol 12:169-180

Christy JH (1987) Female choice and the breeding behavior of the fiddler crab Uca beebei. J Crustac Biol 7:624-635

Christy JH (1988) Pillar function in the fiddler crab Uca beebei (II): Competitive courtship signalling. Ethology 78 : $113-128$

Clutton-Brock TH, Parker GA (1985) Sexual coercion in animal societies. Anim Behav 49:1345-1365

Crane J (1967) Combat and its ritualization in fiddler crabs (Ocypodidae) with special reference to Uca rapax. Zoologica $52: 49-76$ 
Crane $j$ (1975) Fiddler crabs of the world. Ocypodidae: Genus Uca. Princeton University Press, Princeton

Crews D (1975) Effects of different components of male courtship behaviour on environmentally induced ovarian recrudescence and mating preferences in the lizard Anolis carolinensis. Anim Behav 23:349-356

Estabrook CB, Estabrook GF (1989) ACTUS: a solution for the problem of small samples in the analysis of two-way contingency tables. Hist Meth 22:5-8

Faria MM (1994) A luta e o dimorfismo masculino nos caranguejos-violonistas Uca tangeri (Eydoux), (Ocypodidae, Brachyura). In: Almada VC, Oliveira RF (eds) Biologia e comportamento. Actas do I Congresso Nacional de Etologia, ISPA, Lisboa, p 127-136

Greenberg B, Noble GK (1944) Social Behavior of the American chameleon Anolis carolinensis. Physiol Zool 17: $392-439$

Halliday TR (1983) The study of mate choice, In: Bateson PPG (ed) Mate choice. Cambridge University Press, Cambridge, p 3-32

Hyatt GW, Salmon M (1978) Combat in the fiddler crabs Uca pugilator and Uca pugnax: a quantitative analysis. Behaviour 65:182-211

Jennions MD, Backwell PRY (1996) Residency and size affect fight duration and outcome in the fiddler crab Uca annulipes. Biol J Linn Soc 57:293-306

Oliveira RF, Custódio MR (1998) Claw size, waving display and female choice in the European fiddler crab, Uca tangeri. Ethol Ecol Evol 10:241-245

Editorial responsibility: Otto Kinne (Editor),

Oldendorf/Luhe, Germany
Oliveira RF, McGregor PK, Burford FRL, Custódio MR, Latruffe C (1998) Functions of mudballing behaviour in the European fiddler crab Uca tangeri. Anim Behav 55: $1299-1309$

Ostlund-Nilsson S (1998) Female sticklebacks do not prefer dominant or colourful males. Int Behav Ecol Congress abstracts

Ridley M (1981) How the peacock got his tail. New Sci 91: $398-401$

Sigmund WR (1983) Female preference for Anolis carolinensis males as a function of dewlap color and background coloration. J Herpetol 17:137-143

Smuts BB, Smuts RW (1993) Male aggression and sexual coercion of females in nonhuman primates and other mammals: evidence and theoretical implications. Adv Study Behav 22:1-63

Statsoft Inc (1995) Statistica for Windows computer program manual. Statsoft Inc, Tulsa, OK

von Hagen HO (1962) Freilandstudien zur Sexual und Fortpflanszungsbiologie von $U_{C a}$ tangeri in Andalusien. Z Morphol Ökol Tiere 51:611-725

Wolfrath B (1992) Burrowing by the fiddler crab Uca tangeri in the Ria Formosa in Portugal and its influence on the sediment structure. Mar Ecol Prog Ser 85:237-243

Wolfrath B (1993) Observations on the behaviour of the European fiddler crab $U_{C a}$ tangeri. Mar Ecol Prog Ser 100: $111-118$

Yamaguchi I (1977) Studies on the handedness of the fiddler crab, Uca lactea. Biol Bull Woods Hole 152:424-436

Submitted: December 14, 1998; Accepted: May 28, 1999

Proofs received from author(s): November 8,1999 